\title{
Efficiency Method for Methylene Blue Recovery Using Aqueous Two-Phase Systems based on Cholinium-Ionic Liquids
}

\author{
Luan VTD Alencar ${ }^{1}$, Lais MS Passos ${ }^{1}$, Cleide MF Soares ${ }^{2}$, Alvaro S Lima ${ }^{2}$ and Ranyere L Souza ${ }^{2 *}$ \\ ${ }^{1}$ Department of Program in process Engineering, Universidade Tiradentes-UNIT, Brazil
}

${ }^{2}$ Department of Program in process Engineering, ITP Instituto de Tecnologia e Pesquisa, Brazil

Submission: December 3, 2019; Published: January 30, 2020

*Corresponding author: Ranyere L Souza, Tiradentes University, Post-Graduated Program in process Engineering, Avenida Murilo Dantas 300, 49032-490 Aracaju, Sergipe, Brazil.

\begin{abstract}
Aqueous two phase-systems (ATPS) have been introduced as a new approach to remove dyes from aqueous discharges. Thus, this work evaluated the phase formation capacity in ATPS based on different organic solvents (1,3 dioxolane and 2-propanol) and cholinium-based salts (cholinium bitartrate- [Ch][Bit] and cholinium dihydrogencitrate - [Ch][DHCit]). The capacity in two-phase system form for both used solvents was higher with [Ch][Bit]. The ability to recover actual methylene blue dye was then evaluated for the type of phase-forming composition and equilibrium temperature. For solvents evaluated for their ability to form two phases, those formed withshowed greater ability to induce ATPS. The best extraction efficiency $(\approx 92 \%)$ was achieved using the ATPS composed of $48 \mathrm{wt} \%$ of 1,3 dioxolane $+10.5 \mathrm{wt} \%$ of [Ch] [Bit] + water at $15^{\circ} \mathrm{C}$. Thus, it has been shown that ATPS based on organic solvents and cholinium-based ionic liquids have potential for application in dye extraction processes of the textile industry.
\end{abstract}

Keywords: Textile industry; Dyes; Extraction; Partition; Aqueous Two-phase systems; Cholinium; Ionic liquids

\section{Introduction}

Dyes are organic compounds that give colour to materials. They are used in various industries, such as textiles, cosmetics, food, paper and plastic [1,2]. In the past, dyes were usually produced on a small scale from available natural resources, such as insects or plants [3]. However, natural dyes have limited variety and produce muted tones that fade when exposed to sunlight and washing [4]. Because of this, synthetic dyes currently account for the largest share of applications in industries: more than $90 \%$ of industrially used dyes are synthetic [5]. Synthetic dye molecules are complex and stable structures due to the presence of auxochromes (water soluble bonding compounds) and chromophores (sets of atoms in a molecule responsible for its colour), so that the colour of the dyed material is fixed more stably [6]. For this reason, they are composed of complex organic substances which gives these dyes resistance to biodegradation [7]. Among the main industrial sectors, the textile industry stands out for contributing more than half of the existing dye effluent worldwide [6]. These wastes are discharged into bodies of water, changing the colourless, clean water to coloured and contaminated water, this because dyes may be toxic to aquatic organisms and humans due they contain metals and aromatic compounds [6,8-11]. An example is methylene blue dye, which is one of the most commonly used substances for dyeing cotton, wood and silk.

Although it is notstrongly hazardous, it can cause some harmful effects to humans on acute exposure, such as heart rate change, vomiting, cyanosis, jaundice and quadriplegia, and tissue necrosis [12]. Therefore, considering increasingly strict legislations and regulations in worldwide, the associated industries must find the means to treat industrial dye-laden effluents before they are discharged into the environment [13-15]. Consequently, various treatment techniques have been developed to remove synthetic dyes from aqueous solutions [16-19]. However, most treatment methods may present some disadvantages that can make their large-scale application unfeasible, among which generation of hazardous waste, slow degradation rates and high costs stand out [6,20-22]. In this sense, aqueous two-phase systems (ATPS) 
are an efficient method for extracting compounds in various technological processes. They are liquid-liquid extraction systems consisting of the combination of two different compounds in an aqueous medium which, above certain concentrations, forms two liquid phases coexisting in equilibrium, each phase being enriched with one of the compounds [23-28]. The basis for the solutes partitioning in these systems is a direct result of their selective distribution between the two phases, governed by the affinity of the target molecule for a given phase [29,30]. In recent decades, these systems have been introduced as a promising alternative for the removal of dyes from aqueous matrices due to their properties, because they are environmentally safe, recyclable, economical viable; they also involve short processing times and are scalable for application in industrial processes [20,31-33].

Traditionally ATPS are formed by combinations of aqueous solutions of two hydrophilic polymers or, alternatively, a polymer and an inorganic salt [34,35]. Recently, other species also gained prominence as in the case of ionic liquids [29,30,36]. However, the use of ILs has some limitations regarding their thermal and chemical stability, financial cost, toxicity and biodegradability [37-41]. To overcome these challenges, the search for lower cost, safer toxicologically and environmentally sustainable ILs is still a key issue. For this purpose, cholinium-based ILs have gained prominence for ATPS applications. This class of ILs is derived from quaternary ammonium salts, described as important structures in biological processes and used as precursors for the synthesis of vitamins (vitamin B - thiamine) and enzymes that participate in glycide metabolism [42].

Therefore, this work focuses on developing an alternative and efficient method for the recovery of methylene blue from aqueous matrices using organic solvent-based ATPS and choline-based ionic liquids. The systems were investigated for phase formation capability using 2-propanol or 1,3 dioxolane+cholinium bitartrate ([Ch][Bit]) or cholinium dihydrogencitrate ([Ch][DHCit]). Experimental conditions such as solvent type, salt, concentration of phase formers and equilibrium temperature were determined for the dye extraction efficiency.

\section{Materials and Methods}

\section{Materials}

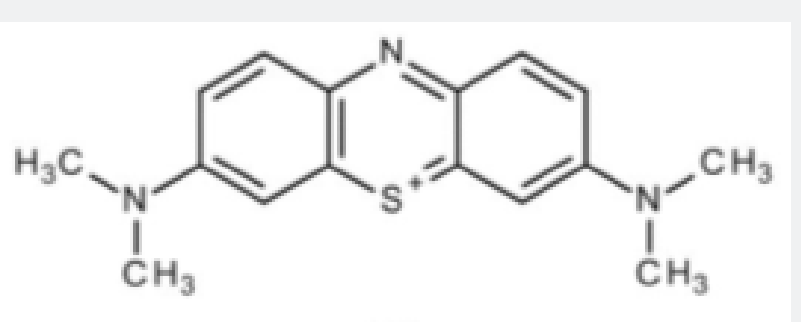

Figure 1: Chemical structure of the methylene blue dye.
The present study was carried out using cholinium bitartrate ([Ch][Bit]), cholinium dihydrogencitrate ([Ch][DHCit]), 2-propanol, 1,3 dioxolane and methylene blue dye. All reagents were purchased from Sigma-Aldrich $₫$, with purities higher than $98 \mathrm{wt} \%$. The water used was purified in a Milli-Q (Direct $\mathrm{Q}^{\circledR} 3 \mathrm{UV}$ ). The chemical structures of the dye are presented in Figure 1.

\section{Experimental Phase Diagrams}

Aqueous solutions at $90 \mathrm{wt} \%$ of 1,3 dioxolane and 2-propanol, and cholinium-based ionic liquid solution at $30 \mathrm{wt} \%$, were prepared for the determination of ternary phase diagrams at $25^{\circ} \mathrm{C}$ and at atmospheric pressure using the cloud point titration method [43]. The systems compositions were determined by weight quantification of all components added considering an uncertainty of \pm 10 - 5 g. The experimental solubility curves were correlated and evaluated Eq. 1 [44]:

$$
\mathrm{w}_{1}=\operatorname{Aexp}\left[\left(\mathrm{Bw}_{2}^{0,5}\right)-\left(\mathrm{Cw}_{2}^{3}\right)\right]
$$

where $w_{1}$ and $w_{2}$ are the mass fraction percentages of the solvent and the cholinium-based ionic liquid, respectively. A, B and $\mathrm{C}$ are fitting parameters obtained by least squares regression.

\section{Dye Partition}

Mixing points were chosen based on the biphasic region of the system phase diagrams. In each system, a dye solution was added to have a dye concentration of $25 \mathrm{mg} . \mathrm{L}^{-1}$ for a total system mass of 5.0g. After thorough homogenization by vigorous shaking, each system was centrifuged at $2500 \mathrm{rpm}$ for $20 \mathrm{~min}$ to induce phase separation, and then allowed to stand for $12 \mathrm{~h}$ at $25^{\circ} \mathrm{C}$ to achieve thermodynamic equilibrium. After this step, complete dye partitioning was achieved between the two phases, so the phase interface was defined. Finally, the top and bottom phases were then carefully separated, weighed and then the volumes of both phases determined. Thus, the dye $(663 \mathrm{~nm})$ was quantified in both phases, through UV spectroscopy using a HACH DR-5000 spectrometer. The partition coefficients of dye (K) was determined, in accordance with Eq. (2):

$$
K=\frac{C_{T}}{C_{B}}
$$

where $C_{T}$ and $C_{B}$ are the dye concentrations in the top and bottom phases, respectively.

In order to evaluate the dye extraction efficiencies for top phase $\left(\mathrm{EE}_{\mathrm{T}}, \%\right)$ and bottom phase $\left(\mathrm{EE}_{\mathrm{B}}, \%\right)$ and the volume ratio $(\mathrm{Rv})$ in each ATPS, the following equations were used:

$$
\begin{gathered}
\mathrm{R}_{\mathrm{V}}=\frac{\mathrm{V}_{\mathrm{T}}}{\mathrm{V}_{\mathrm{B}}}(3) \\
\mathrm{EE}_{\mathrm{T}}, \%=\frac{100}{1+\left(\frac{1}{\mathrm{R}_{\mathrm{V}} \mathrm{K}}\right)}(4)
\end{gathered}
$$




$$
\mathrm{EE}_{\mathrm{B}}, \%=\frac{100}{1+\mathrm{R}_{\mathrm{V}} \mathrm{K}}
$$

where $\mathrm{V}$ is the phase volume, and $\mathrm{T}$ and $\mathrm{B}$ correspond to the top and bottom phases, respectively.

\section{Thermodynamic Properties}

The thermodynamic functions calculated for the transfer of the dye, namely the molar Gibbs energy $\left(\Delta G^{\circ}{ }_{m}\right)$, the molar enthalpy $\left(\Delta \mathrm{H}_{\mathrm{m}}^{\circ}\right)$ and the molar entropy of transfer $\left(\Delta \mathrm{S}_{\mathrm{m}}^{\circ}\right)$, Eq. (6)-(8) were used.

$$
\begin{aligned}
\ln K_{E} & =-\frac{\ddot{A} H^{\circ} m}{R} \times \frac{1}{T}+\frac{\ddot{A} S_{m}^{\circ}}{R}(6) \\
\ddot{A} G^{\circ} m & =\ddot{A} H^{\circ}{ }_{m}-T \ddot{A} S^{\circ} m
\end{aligned}
$$

$$
\ddot{A} G_{m}^{\circ}=-R \ln \left(K_{E}\right)
$$

\section{Results and Discussion}

\section{Phase Diagrams}

The ability of the differents cholinium compounds to induce ATPS formation in presence of solvents was evaluated. Aqueous solutions of each cholinium-based ionic liquids ([Ch] [Bit] or [Ch]
[DHCit]) (30 wt\%) and of solutions of each solvent (1,3 dioxolane or 2-propanol) (90wt\%) were initially prepared and used for the determination of the binodal curves at $25^{\circ} \mathrm{C}$ and atmospheric pressure. These binodal curves are shown in Figure 2. Through the cloud point titration method, it was possible to observe the ability of the solvents studied to form two phases with both investigated ionic liquid. This is because the high polarity due to the charge of the carboxylate groups in both [Ch][Bit] and [Ch][DHCit] increases their affinity for water, which induced a salting-out effect on solvents, leading to the formation of the ATPS [45]. Of the ATPS studied, [Ch] [Bit] showed the highest ability to induce ATPS as shown in Figure 2. The ability of the cholinium-based ionic liquids to promote the formation of ATPS with 1,3 dioxolane and 2-propanol follows the trend: [Ch][Bit] > [Ch][DHCit]. Considering that these cholinium have the same cation but different anions, the phase-forming ability of these ionic liquids must be determined by the nature of the anions. The ability to induce phase separation of these cholinium-based ionic liquids is determined by the capacity of the anion to form hydration complexes. The data of the binodal curves in mass fraction units, as well as the respective regression parameters (A, B and C) obtained by applying Eq. 1 [44], standard deviations and correlation coefficients $\left(\mathrm{R}^{2}\right)$ are provided in Table 1. In the Table 1 shows that good correlations $\left(R^{2}>0.99\right)$ were obtained for the equation used, indicating that this accessory can be used to predict data from a particular phase diagram region where no experimental data are available.

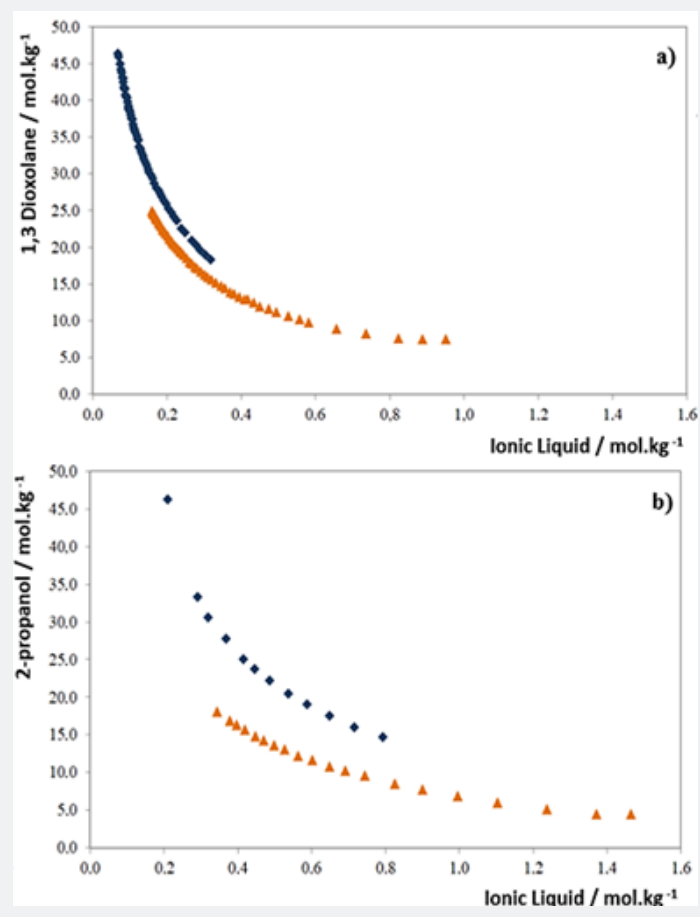

Figure 2: Binodal curves for ternary systems composed of solvents + cholinium-based ionic liquids + water at $25^{\circ} \mathrm{C}$ and atmospheric pressure. a) 1,3 Dioxolane and b) 2-propanol; $(\diamond)[\mathrm{Ch}][\mathrm{DHCit}]$ and $(\Delta)[\mathrm{Ch}][\mathrm{Bit}]$. 
Table 1: The data of the binodal curves in mass fraction units, as well as the respective regression parameters (A, B and C) obtained by applying Eq. 1, with standard deviations and correlation coefficients $\left(R^{2}\right)$ for the ATPS composed of solvents $(1,3$ dioxolane or 2 -propanol) + cholinium-based ionic liquids $([\mathrm{Ch}][\mathrm{Bit}]$ or $[\mathrm{Ch}][\mathrm{DHCit}])+$ water at $25^{\circ} \mathrm{C}$ and atmospheric pressure.

\begin{tabular}{|c|c|c|c|c|c|c|c|c|}
\hline & \multicolumn{4}{|c|}{ 1,3 Dioxolane } & \multicolumn{4}{|c|}{ 2-propanol } \\
\hline & \multicolumn{2}{|c|}{$[\mathrm{Ch}][\mathrm{Bit}]$} & \multicolumn{2}{|c|}{$[\mathrm{Ch}][\mathrm{DHCit}]$} & \multicolumn{2}{|c|}{$[\mathrm{Ch}][\mathrm{Bit}]$} & \multicolumn{2}{|c|}{$[\mathrm{Ch}][\mathrm{DHCit}]$} \\
\hline $\mathrm{A}$ & \multicolumn{2}{|c|}{$109,62 \pm 0,84$} & \multicolumn{2}{|c|}{$97,55 \pm 0,15$} & \multicolumn{2}{|c|}{$113,9 \pm 3,16$} & \multicolumn{2}{|c|}{$136,3 \pm 8,72$} \\
\hline B & \multicolumn{2}{|c|}{$-0.263 \pm 0.003$} & \multicolumn{2}{|c|}{$-0.163 \pm 0.001$} & \multicolumn{2}{|c|}{$-0.2219 \pm 0.008$} & \multicolumn{2}{|c|}{$-0.2131 \pm 0.029$} \\
\hline $\mathrm{C}$ & \multicolumn{2}{|c|}{$2,3 \times 10^{-7} \pm 1,6 \times 10^{-6}$} & \multicolumn{2}{|c|}{$8,5 \times 10^{-5} \pm 2,9 \times 10^{-6}$} & \multicolumn{2}{|c|}{$1,28 \times 10^{-5} \pm 9,44 \times 10^{-7}$} & \multicolumn{2}{|c|}{$8,01 \times 10^{-6} \pm 1,51 \times 10^{-5}$} \\
\hline \multirow[t]{23}{*}{$\mathrm{R}^{2}$} & \multicolumn{2}{|c|}{0.9983} & \multicolumn{2}{|c|}{0.9998} & \multicolumn{2}{|c|}{0.9987} & \multicolumn{2}{|c|}{0.9992} \\
\hline & $100 \mathrm{w}_{1}$ & $100 \mathrm{w}_{2}$ & $100 \mathrm{w}_{1}$ & $100 \mathrm{w}_{2}$ & $100 \mathrm{w}_{1}$ & $100 \mathrm{w}_{2}$ & $100 \mathrm{w}_{1}$ & $100 \mathrm{w}_{2}$ \\
\hline & 75.28 & 2.82 & 77.79 & 1.74 & 57.23 & 9.21 & 93.07 & 2.37 \\
\hline & 68.13 & 3.33 & 74.36 & 2.84 & 55.52 & 10.06 & 92.46 & 2.76 \\
\hline & 58.51 & 4.05 & 66.62 & 4.33 & 54.71 & 10.48 & 91.69 & 3.45 \\
\hline & 54.53 & 5.01 & 60 & 6.41 & 53.72 & 10.99 & 91.27 & 3.98 \\
\hline & 50.09 & 5.77 & 57.46 & 7.75 & 52.32 & 11.65 & 90.85 & 4.58 \\
\hline & 46.38 & 6.41 & 54.38 & 8.35 & 51.43 & 12.15 & 90.65 & 5.19 \\
\hline & 43.73 & 7.1 & 52.53 & 9.24 & 50.18 & 12.81 & 90.32 & 5.88 \\
\hline & 41.39 & 7.69 & 50.89 & 9.99 & 49.15 & 13.46 & 77.43 & 5.81 \\
\hline & 39.41 & 8.22 & 49.25 & 10.76 & 47.59 & 14.26 & 71.16 & 7.89 \\
\hline & 37.58 & 8.69 & 47 & 12.3 & 46.24 & 15.09 & 69.43 & 8.63 \\
\hline & 35.53 & 9.6 & 44.18 & 13.54 & 44.46 & 16.07 & 67.31 & 9.81 \\
\hline & 34 & 9.99 & 42.39 & 14.82 & 43.12 & 16.95 & 64.95 & 10.89 \\
\hline & 32.25 & 10.79 & 40.65 & 16.12 & 41.53 & 18.03 & 63.78 & 11.62 \\
\hline & 30.4 & 11.82 & 39.12 & 17.25 & 38.67 & 19.58 & 62.18 & 12.52 \\
\hline & 27.67 & 13.66 & 33.87 & 22.35 & 36.52 & 20.99 & 60.23 & 13.67 \\
\hline & 24.76 & 15.67 & 18.87 & 36.05 & 33.69 & 22.72 & 58.53 & 14.79 \\
\hline & 16.53 & 23.29 & 17.47 & 37.83 & 30.92 & 24.57 & 56.44 & 16.07 \\
\hline & 15.84 & 24.65 & 15.12 & 40.4 & 27.59 & 26.77 & 54.33 & 17.45 \\
\hline & 14.99 & 25.93 & & & 25.13 & 28.83 & 52.1 & 18.95 \\
\hline & 9.3 & 38.97 & & & 24.83 & 30.19 & & \\
\hline & 8.43 & 41.31 & & & & & & \\
\hline
\end{tabular}

\section{Dye partition}

The actual ability of ATPS to partition of methylene blue dye was evaluated by analyzing systems composed of different cholinium-based ionic liquids ([Ch][DHCit] or [Ch][Bit]) and 1,3 dioxolane. Mixing points were determined based on the phase diagrams presented in the previous topic (Figure 2). The systems were formed with $63 \mathrm{wt} \%$ of 1.3 dioxolane $+11 \mathrm{wt} \%$ of choliniumbased ionic liquids + solution dye $\left(\approx 25 \mathrm{mg} \cdot \mathrm{L}^{-1}\right)$ at $25^{\circ} \mathrm{C}$ and atmospheric pressure. In Figure 3 shows the extraction results for the studied systems. The results showed a higher affinity for the bottom phase of the system (ionic liquid-rich phase), partition coefficient $(\mathrm{K})<1$. The migration of the methylene blue dye was preferably higher for the [Ch][Bit], due mainly the affinity of the dye for ionic compounds (when compared with the solvent) and more hydrophobic (when compared between the ionic liquids) [46], as a result of an adequate balance of interactions. Thus, for an optimization of the extraction of methylene blue dye, the investigation of the effect of the concentration of the components on its partitioning in ATPS based on [Ch][Bit] was performed (Figure 4). The systems were evaluated at different concentrations of 1,3 dioxolane (48-63 wt\%), and as solvent concentration decreased, bottom phase dye extraction increased from $\approx 51 \%$ to $\approx 89 \%$ (Figure 4 (a)). Subsequently, the effect of ionic liquid concentration on ATPS with fixed concentrations of $48 \mathrm{wt} \%$ of 1,3 dioxolane was investigated (Figure 4 (b)). It can be noted that the decrease in [Ch][Bit] concentration increased the migration of the methylene blue dye to the bottom phase, reaching a maximum extraction of $\approx 90.3 \%$ in the ATPS based on $48 \mathrm{wt} \%$ of 1,3 dioxolane 


\section{Current Trends in Fashion Technology \& Textile Engineering}

and $10.5 \mathrm{wt} \%$ of [Ch][Bit]. Values lower than $48 \mathrm{wt} \%$ of solvent not possible due to the limit of the binodal curve. (Table 2) composition and $10.5 \mathrm{wt} \%$ of the ionic liquid concentration are

Table 2: The data of the binodal curves in mass fraction units, as well as the respective regression parameters $(A, B$ and $C)$ obtained by applying Eq. 1. with standard deviations and correlation coefficients (R2) for the ATPS composed of cholinium-based ionic liquids (w1) ([Ch][Bit] or [Ch] $[\mathrm{DHCit}])+2$-propanol (w2) + water at $25^{\circ} \mathrm{C}$ and atmospheric pressure.

\begin{tabular}{|c|c|c|c|c|}
\hline \multicolumn{5}{|c|}{ 2-propanol } \\
\hline \multicolumn{3}{|c|}{$[\mathrm{Ch}][\mathrm{Bit}]$} & \multicolumn{2}{|c|}{ [Ch][DHCit] } \\
\hline $\mathrm{A}$ & \multicolumn{2}{|c|}{$113.9 \pm 3.16$} & \multicolumn{2}{|c|}{$120.5 \pm 1.68$} \\
\hline $\mathrm{B}$ & \multicolumn{2}{|c|}{$-0.2219 \pm 0.008$} & \multicolumn{2}{|c|}{$-0.185 \pm 0.005$} \\
\hline $\mathrm{C}$ & \multicolumn{2}{|c|}{$1.28 \times 10^{-5} \pm 9.44 \times 10^{-5}$} & \multicolumn{2}{|c|}{$4.36 \times 10^{-6} \pm 1.53 \times 10^{-6}$} \\
\hline \multirow[t]{22}{*}{$\mathrm{R}^{2}$} & \multicolumn{2}{|c|}{0.9987} & \multicolumn{2}{|c|}{0.9992} \\
\hline & $100 \mathrm{w}_{1}$ & $100 \mathrm{w}_{2}$ & $100 \mathrm{w}_{1}$ & $100 \mathrm{w}_{2}$ \\
\hline & 30.187 & 24.828 & 18.955 & 52.105 \\
\hline & 28.832 & 25.13 & 17.447 & 54.328 \\
\hline & 26.765 & 27.595 & 16.074 & 56.441 \\
\hline & 24.57 & 30.919 & 14.787 & 58.529 \\
\hline & 22.721 & 33.69 & 13.669 & 60.235 \\
\hline & 20.991 & 36.522 & 12.523 & 62.18 \\
\hline & 19.581 & 38.668 & 11.62 & 63.784 \\
\hline & 18.025 & 41.526 & 10.886 & 64.945 \\
\hline & 16.953 & 43.123 & 9.814 & 67.305 \\
\hline & 16.07 & 44.457 & 8.633 & 69.427 \\
\hline & 15.09 & 46.243 & 7.891 & 71.162 \\
\hline & 14.265 & 47.588 & 5.807 & 77.435 \\
\hline & 13.464 & 49.152 & & \\
\hline & 12.808 & 50.176 & & \\
\hline & 12.152 & 51.431 & & \\
\hline & 11.652 & 52.32 & & \\
\hline & 10.989 & 53.721 & & \\
\hline & 10.485 & 54.709 & & \\
\hline & 10.059 & 55.516 & & \\
\hline & 9.214 & 57.232 & & \\
\hline
\end{tabular}

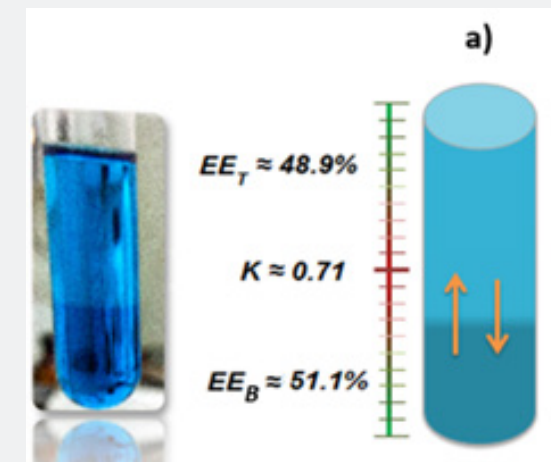

[Bit]

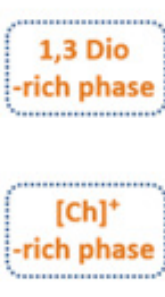

$[\mathrm{Ch}]^{+}$ rich phase,

[DHcit] b)
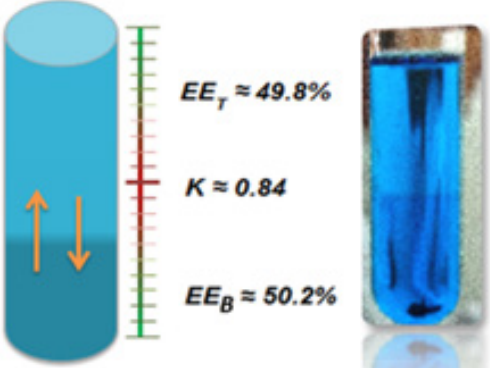

12

Figure 3: Partition and extraction aspect of the methylene blue dye in ATPS based on 1,3 dioxolane and cholinium-based ionic liquids. a) [Ch][Bit] and b) [Ch][DHCit]. 

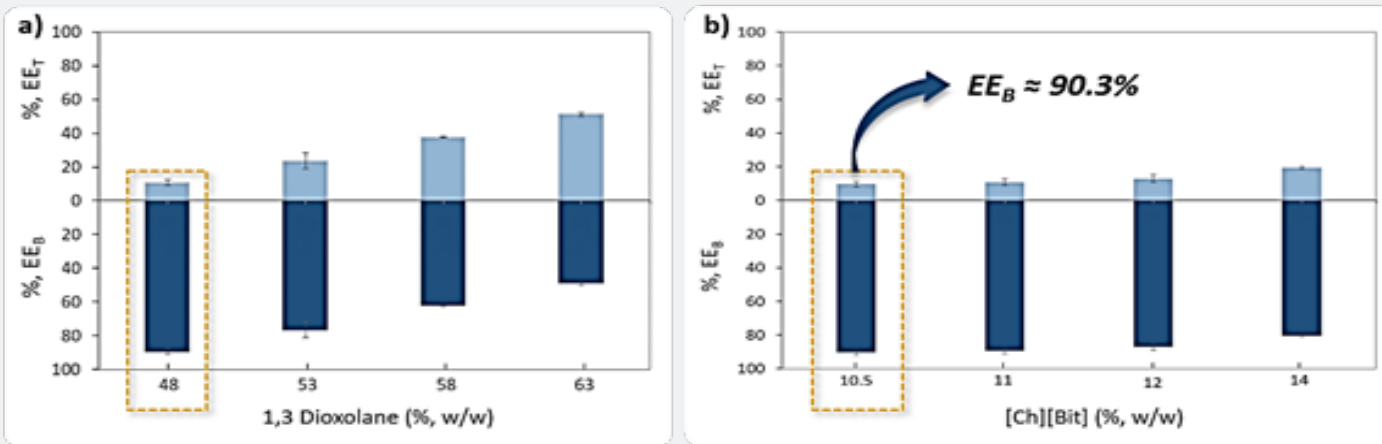

Figure 4: Results found for the extraction efficiency in the top phase (EET) and the bottom phase (EEB) of methylene blue by applying systems composed of: a) different 1,3 dioxolane concentrations $(48 ; 53 ; 58$ and $63 \mathrm{wt} \%)+11 \mathrm{wt} \%$ of [Ch] [Bit] $+0.2 \mathrm{wt} \%$ of dye + water and b) $48 \mathrm{wt} \%$ of 1,3 dioxolane + different [Ch][Bit] concentrations $(10.5 ; 11 ; 12$ and $14 \mathrm{wt} \%)+0.2 \mathrm{wt} \%$ of dye + water, at $25^{\circ} \mathrm{C}$ and atmospheric pressure.

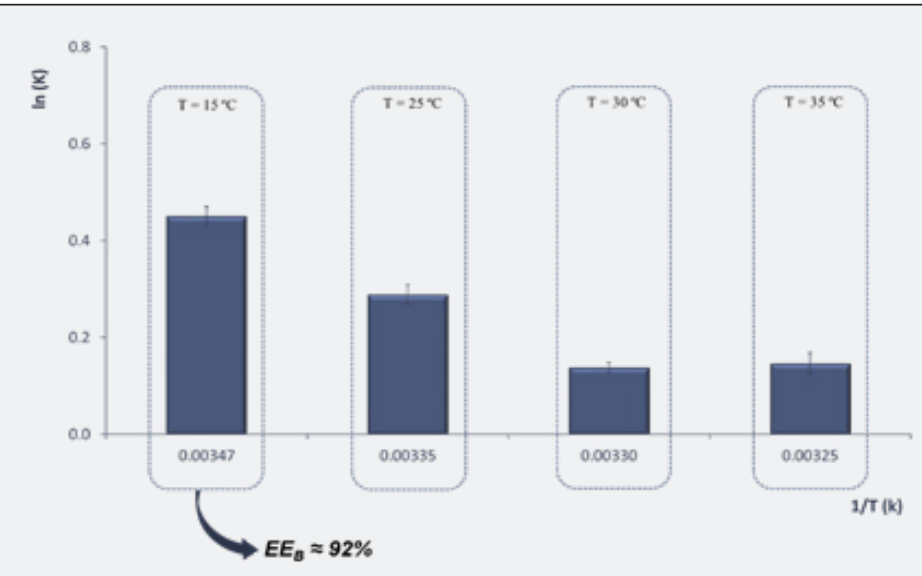

Figure 5: Effect of temperature on partition coefficient $(\mathrm{K})$ of methylene blue dye for the ATPS based on 1,3 dioxolane and [Ch][Bit].

The influence of temperature on dye extraction was also studied using ATPS composed of 1,3 dioxolane at $48 \mathrm{wt} \%$ and [Ch][Bit] at $10.5 \mathrm{wt} \%$ (Figure 5 ). The temperature of equilibrium was changed from 15 to $35^{\circ} \mathrm{C}$. A decrease in temperature slightly favours the migration of dye for the ionic liquid-rich phase until the $15^{\circ} \mathrm{C}$, reaching a maximum extraction of $\approx 92 \%$. The calculated value for $\Delta G_{m}^{\circ}(-0.63 \mathrm{KJ} / \mathrm{mol})$ is negative, reflecting therefore the spontaneous and preferential partitioning of the dye for the ionic liquid-rich phase $(K<1)$. The migration process of the dye from the 1,3 dioxolane-rich phase to the ionic liquid-rich phase is exothermic $\Delta \mathrm{H}^{\circ}{ }_{\mathrm{m}}=-12.25 \mathrm{KJ} / \mathrm{mol}$ ) and mainly governed by entropic forces $\left(\Delta \mathrm{S}_{\mathrm{m}}^{\circ}=-38.82 \mathrm{~J} / \mathrm{mol} . \mathrm{K}\right)$, since $-\mathrm{T} \Delta \mathrm{S}_{\mathrm{m}}^{\circ}>\Delta \mathrm{H}_{\mathrm{m}}^{\circ}$.

\section{Conclusion}

Binodal curves were obtained for the novel ATPS formed by organic solvents (1,3 dioxolane and 2-propanol) and choliniumbased ionic liquids ([Ch][Bit] and [Ch][DHcit]). The ability of these cholinium-based ionic liquids to promote phase formation with the investigated solvents follows the trend: [Ch] [Bit]> [Ch]
[DHCit]. The ATPS based on 1,3 dioxylane and the both choliniumbased ionic liquids were evaluated for their actual ability to recover the methylene blue dye. The most effective dye extraction was obtained using ATPS composed of $48 \mathrm{wt} \%$ of 1,3 dioxolane and $10.5 \mathrm{wt} \%$ of $[\mathrm{Ch}][\mathrm{Bit}]+$ water at $15^{\circ} \mathrm{C}$ and at atmospheric pressure, which obtained an $\mathrm{EEB} \approx 92 \%$ to the [Ch][Bit]-rich phase. Thus, the application potential of this technology is inherent to the results obtained in this work, which showed that ATPS based on solvents and cholinium-based ionic liquids have a great potential of application in the recovery of dyes of the textile industry.

\section{Acknowledgments}

The authors acknowledge the financial support of Coordenação de Aperfeiçoamento de Pessoal de Nível Superior - Brasil (CAPES) - Finance Code 001; Conselho Nacional de Desenvolvimento Científico e Tecnológico (CNPq).

\section{References}

1. Aksu Z (2005) Application of biosorption for the removal of organic pollutants: a review. Process Biochem 40: 997-1026. 
2. Suteu D, Bilba D, Coseri S (2014) Macroporous polymeric ion exchangers as adsorbents for the removal of cationic dye basic blue 9 from aqueous solutions. J Appl Polym Sci 131(1): 39620.

3. Kant R (2012) Textile dyeing industry an environmental hazard. Nat Sci 14(1): 22-26.

4. Solís M, Solís A, Pérez HI, Manjarrez N, Flores M (2012) Microbial decolouration of azo dyes: A review. Process Biochem 47(12): 17231748.

5. Nagendrappa G (2010) Sir William Henry Perkin: The man and his 'Mauve'. Resonance pp: 779-793.

6. Katheresan V, Kansedo J, Lau SY (2018) Efficiency of various recent wastewater dye removal methods: A review. J Environ Chem Eng 6: 4676-4697.

7. Al-Alwani MAM, Ludin NA, Mohamad AB, Kadhum AAH, Mukhlus A (2018) Application of dyes extracted from Alternanthera dentata leaves and Musa acuminata bracts as natural sensitizers for dye-sensitized solar cells. Spectrochim Acta A Mol Biomol Spectrosc 192: 487-498.

8. Gupta VK, Suhas (2009) Application of low-cost adsorbents for dye removal-A review. J Environ Manage 90(8): 2313-2342.

9. Patra G, Barnwal R, Behera SK, Meikap BC (2018) Removal of dyes from aqueous solution by sorption with fly ash using a hydrocyclone. J Environ Chem Eng 6: 5204-5211.

10. Holkar CR, Jadhav AJ, Pinjari DV, Mahamuni NM, Pandit AB (2016) A critical review on textile wastewater treatments: Possible approaches. J Environ Manage 182: 351-366.

11. Yagub MT, Sen TK, Afroze S, Ang HM (2014) Dye and its removal from aqueous solution by adsorption: A review. Adv Colloid Interface Sci 209: 172-184.

12. Kumar KV, Kumaran A (2005) Removal of methylene blue by mango seed kernel powder. Biochem Eng J 27(1): 83-93.

13. Hessel C, Allegre C, Maisseu M, Charbit F, Moulin P (2007) Guidelines and legislation for dye house effluents. J Environ Manage 83(2): 171180.

14. Liu L, Zhang J, Tan Y, Jiang Y, Hu M, et al. (2014) Rapid decolorization of anthraquinone and triphenylmethane dye using chloroperoxidase: Catalytic mechanism, analysis of products and degradation route Chem Eng J 244: 9-18.

15. Vajnhandl S, Valh JV (2014) The status of water reuse in European textile sector. J Environ Manage 141: 29-35.

16. Gadekar MR, Ahammed MM (2016) Coagulation/flocculation process for dye removal using water treatment residuals: modelling through artificial neural networks. Desalin Water Treat 57(55): 26392-26400.

17. Módenes AN, Espinoza-Quiñones FR, Borba FH, Manenti DR (2012) Performance evaluation of an integrated photo-FentonElectrocoagulation process applied to pollutant removal from tannery effluent in batch system. Chem Eng J 197: 1-9.

18. Cotillas S, Llanos J, Cañizares P, Clematis D, Cerisola G, et al. (2018) Removal of Procion Red MX-5B dye from wastewater by conductivediamond electrochemical oxidation. Electrochim Acta 263: 1-7.

19. Manenti DR, Soares PA, Módenes AN, Espinoza-Quiñones FR, Boaventura RAR, et al. (2015) Insights into solar photo-Fenton process using iron(III)-organic ligand complexes applied to real textile wastewater treatment. Chem Eng J 266: 203-212.

20. Alvarenga JM, Fideles RA, Silva MV, Murari GF, Taylor JG, et al. (2015) Partition study of textile dye Remazol Yellow Gold RNL in aqueous twophase systems. Fluid Phase Equilibr 391: 1-8.
21. Nidheesh PV, Gandhimathi R, Ramesh ST (2013) Degradation of dyes from aqueous solution by Fenton processes: a review. Environ Sci Pollut R 20(4): 2099-2132.

22. Sinha A, Lulu S, Sundararajan Vino, Banerjee S, Acharjee S, et al. (2018) Degradation of reactive green dye and textile effluent by Candida sp. VITJASS isolated from wetland paddy rhizosphere soil. J Environ Chem Eng 6: 5150-5159.

23. Baghlani M, Sadeghi R (2018) The capability of tetra alkyl ammonium bromides for aqueous biphasic systems formation with both polymers and electrolytes in aqueous solutions. Fluid Phase Equilibr 465: 34-47.

24. Neves CMSS, Shahriari S, Lemus J, Pereira JFB, Freire MG, et al. (2016) Aqueous biphasic systems composed of ionic liquids and polypropylene glycol: insights into their liquid-liquid demixing mechanisms. Phys Chem Chem Phys 18: 20571-20582.

25. Pereira JFB, Kurnia KA, Freire MG, Coutinho JAP, Rogers RD (2015) Controlling the Formation of Ionic-Liquid-based Aqueous Biphasic Systems by Changing the Hydrogen-Bonding Ability of Polyethylene Glycol End Groups. ChemPhysChem 16(10): 2219-2225.

26. Rodrigues GD, Silva MdCH, Silva LHM, Teixeira LS, Andrade VM (2009) Liquid-Liquid Phase Equilibrium of Triblock Copolymer L64, Poly(ethylene oxide-b-propylene oxide-b-ethylene oxide), with Sulfate Salts from (278.15 to 298.15) K. J Chem Eng Data 54: 1894-1898.

27. Sanglard MG, Farias FO, Sosa FHB, Santos TPM, Igarashi-Mafra L, et al. (2018) Measurement and correlation of aqueous biphasic systems composed of alcohol (1-propanol/2-propanol/tert-butanol) $+(\mathrm{NH} 4) 2 \mathrm{SO} 4+\mathrm{H} 20$ at $298 \mathrm{~K}$ and a textile dye partition. Fluid Phase Equilibr 466: 7-13.

28. Santos RP, Souza LM, Balieiro AL, Soares CMF, Lima ÁS, et al. (2018) Integrated process of extraction and purification of betanin from Opuntia ficus-indica using aqueous two-phase systems based on THF and sodium salts. Separation Science and Technology 53(5): 734-744.

29. Ferreira AM, Coutinho JAP, Fernandes AM, Freire MG (2014) Complete removal of textile dyes from aqueous media using ionic-liquid-based aqueous two-phase systems. Sep Purif Technol 128: 58-66.

30. Mourão T, Tomé LC, Florindo C, Rebelo LPN, Marrucho IM (2014) Understanding the Role of Cholinium Carboxylate Ionic Liquids in PEGBased Aqueous Biphasic Systems. ACS Sustain Chem Eng 2: 2426-2434.

31. Borges GA, Silva LP, Penido JA, de Lemos LR, Mageste AB, et al. (2016) A method for dye extraction using an aqueous two-phase system: Effect of co-occurrence of contaminants in textile industry wastewater. J Environ Manage 183: 196-203.

32. Passos H, Tavares DJP, Ferreira AM, Freire MG, Coutinho JAP (2016) Are Aqueous Biphasic Systems Composed of Deep Eutectic Solvents Ternary or Quaternary Systems? ACS Sustain Chem Eng 4(5): 28812886.

33. Zhang H, Wang Y, Zhou Y, Chen J, Wei X, et al. (2018) Aqueous biphasic systems formed by deep eutectic solvent and new-type salts for the high-performance extraction of pigments. Talanta 181: 210-216.

34. Kenneth A Giuliano (1995) Aqueous two-phase partitioning, physical chemistry and bioanalytical application. In: Marcell Dekker, Boris Y Zaslavsky, New York, pp: 1-696.

35. Ruiz Ruiz F, Benavides J, Aguilar O, Rito-Palomares M (2012) Aqueous two-phase affinity partitioning systems: Current applications and trends. Journal of Chromatography A 1244: 1-13.

36. Souza RL, Lima RA, Coutinho JAP, Soares CMF, Lima ÁS (2015) Aqueous two-phase systems based on cholinium salts and tetrahydrofuran and their use for lipase purification. Sep Purif Technol 155: 118-126. 
37. Li XY, Zhou J, Yu M, Wang JJ, Pei YC (2009) Toxic effects of 1-methyl-3octylimidazolium bromide on the early embryonic development of the frog Rana nigromaculata. Ecotox Environ Safe 72(2): 552-556.

38. Stolte S, Steudte S, Areitioaurtena O, Pagano F, Thöming J, et al. (2012) Ionic liquids as lubricants or lubrication additives: An ecotoxicity and biodegradability assessment. Chemosphere 89(9): 1135-1141.

39. Thuy Pham TP, Cho CW, Yun YS (2010) Environmental fate and toxicity of ionic liquids: A review. Water Research 44(2): 352-372.

40. Ventura SP, Gonçalves AM, Sintra T, Pereira JL, Gonçalves F, et al. (2013) Designing ionic liquids: the chemical structure role in the toxicity. Ecotoxicology 22(1): 1-12.

41. Yu M, Li SM, Li XY, Zhang BJ, Wang JJ (2008) Acute effects of 1-octyl3-methylimidazolium bromide ionic liquid on the antioxidant enzyme system of mouse liver. Ecotox Environ Safe 71(3): 903-908.
42. Meck WH, Williams CL (1999) Choline supplementation during prenatal development reduces proactive interference in spatial memory. Developmental Brain Research 118(1-2): 51-59.

43. Souza RL, Lima RA, Coutinho JAP, Soares CMF, Lima ÁS (2015) Novel aqueous two-phase systems based on tetrahydrofuran and potassium phosphate buffer for purification of lipase. Process Biochem 50: 14591467.

44. Merchuk JC, Andrews BA, Asenjo JA (1998) Aqueous two-phase systems for protein separation: Studies on phase inversion. J Chromatogr B Biomed Sci Appl 711(1-2): 285-293.

45. Huddleston J, Veide A, Köhler K, Flanagan J, Enfors SO, et al. (1991) The molecular basis of partitioning in aqueous two-phase systems. Trends Biotechnol 9(11): 381-388.

46. Chemspider (2019) The free chemical database.

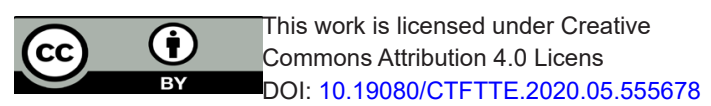

\section{Your next submission with Juniper Publishers} will reach you the below assets

- Quality Editorial service

- Swift Peer Review

- Reprints availability

- E-prints Service

- Manuscript Podcast for convenient understanding

- Global attainment for your research

- Manuscript accessibility in different formats

( Pdf, E-pub, Full Text, Audio)

- Unceasing customer service

Track the below URL for one-step submission https://juniperpublishers.com/online-submission.php 